\title{
POSSIBLE DEFECTS IN WOOD, WOOD PARAMETERS VARIABILITY AND SOME OF ITS INFLUENCE ON QUALITY OF BUILDING STRUCTURE
}

\author{
Jaroslaw MALESZA \\ Department of Structural Mechanics, Faculty of Civil and Environmental Engineering, \\ Bialystok University of Technology, Wiejska 45 E, 15-351, Bialystok, Poland
}

Received 26 June 2015; accepted 28 November 2015

\begin{abstract}
Paper specifies the wood-framed with sheathing construction including phases of realization and exploitation. Methods of investigation based on practice and theory has been employed where practical identification of processes and their phases were presented with theoretical description of structure deformation within the exploitation period. Obtained results of investigations are presented in the form of technologic and mechanic of structure diagrams for buildings with adequate algorithms of analysis. Paper presents practical systematic of construction stages, technological problems and hazards in respect of loading and construction technology with method of computation of vertical deformations of building. Paper presents evaluation of contribution of wood defects in response to loading in the wood-framed residential building in exploitation process. Location of knots, allocation of pith in the elements cross section, defects of slope of grain and influence of moisture decreasing is examined in the paper. The wood-framed with sheathing in the form of large panel or modular three dimensional 3D elements are the most often used technology. This kind of buildings are actually constructed up to four story as a multifamily or varying universal buildings like school, kid-garden or offices. Low dead load from 0.30 to $1.00 \mathrm{kN} / \mathrm{m}^{2}$ and its favorable proportion to the live load increase energy saving factor in realization and within the exploitation time. Low own weight of structure enables complete prefabrication of wall, floor and roof panels, improving quality of construction and shortening time of construction. Process of prefabrication, wide assortment and variety of factory production does not require time consuming processes and complicated moulds or shuttering indispensable in precast RC structural elements.
\end{abstract}

Keywords: timber structure, wood-framed construction, modular buildings, construction phases, shrinkage and swelling deformations, bearing displacements.

\section{Introduction}

Light wood-framed with sheathing buildings represent significant percent of residential and small commercial construction realized in several European countries. Multistory buildings in the wood-framed technology or based on this technology modular system are constructed also in Europe. Increased interest in energy saving and ecological requirements give the green light for more economic building construction. The woodframed construction technology is widely accepted and realized in the United States, Canada, almost all
Scandinavian countries, Australia, Japan and within last three decades in Germany and in Poland. Wood is the most renewable building material, when the economy of lumber resources is provided with ecological aspects, adequately saving the natural remaining old forest complexes. In technology advanced countries almost $47 \%$ of building materials are based on wood and wood derivatives, while at the same time they are consuming $4 \%$ of energy in the process of production (Malesza, Miedzialowski 2011). Paper presents specifics of the wood-framed building of varying technol- 
ogy construction, stages of realization from element to whole segments and deformations rising in the exploitation time.

Extensive share of timber buildings in the overall branch of building construction requires increased attention in selection of wood and its quality for structure. Special attention shall be paid to wood quality and variability of wood characteristics and parameters while selecting lumber for structure. This parameters variability is related to kind of wood and water content in wood and it has a significant impact on wood properties within the time of woodwork and exploitation of timber structure.

Wood is made of thousands of small cells, which are long, slender tubes. Most of the cells are oriented parallel to the length of the tree trunk, and this gives wood a grain in that direction. Cutting across the tree stem, it is exposed the open ends of thousands of cells (Karacabeyli, Desjardins 2011; Schickhofer, Thiel 2011). This end grain absorbs (or releases) water much more quickly than the other wood surfaces, which can have important implications for trying to keep wood dry and protected from decay and insects.

Wood is an anisotropic material and its response depends on direction of loading in consequence. This effect is significantly influencing strain resulted from loading directed perpendicular to the grain (Miedzialowski, Malesza 2006).

The other factor determining deformation is water content in timber element and consequence of moisture changes in material. Moisture is held in wood in two ways. Water contained in the cell cavity is known as free water, while water contained within the cell walls is known as bound water. Two ranges of moisture can be recognized in wood: capillary range (above the grain saturation point) and hygroscopic range (average moisture $\mathrm{w}<30 \%$ ).

Chemically not bounded, free water removal cause process of drying in wood (Asiz et al. 2005). The moisture content that corresponds to a complete loss of free water (with 100 percent of the bound water remaining) is known as the fiber saturation point. The moisture content changes below the fiber saturation point cause lost of bound water and adequate changes of wood volume. With moisture content changes below the fiber saturation point, bound water is lost and volume of wood changes occur. If moisture is lost, wood shrinks, if moisture is gained, wood swells. Decreases in moisture content below the fiber saturation point are accompanied by increases in strength properties. Results from investigations show that strength properties peak at around 10 to 15 percent of moisture content.

Increase in moisture content in hygroscopic range cause lost of timber strength; in the capillary range (above the fiber saturation point), influence on strength is low and strength is almost unchanged. In the range of moisture content from $W=8 \%$ to $W=18 \%$ it can be assumed that increase in moisture on $1 \%$ cause the linear drop in strength 3 to 6\% (Malesza et al. 2013). Compressive strength significantly depends on water content comparing to tensile strength.

\section{Wood and its share in building construction}

New technology when lower class lumber, development of technology permitting use of boards manufactured on the base of low quality wood, use of glulam (GL) and cross laminated timber (CLT), expanded possibility of use timber in varying sectors of building construction. Contrary to concrete wood has very low own weight and possibility to bear the same live load in the range of expected imposed loadings in residential buildings. So more the construction process, easy disassembling, load duration time foreseen for typical building construction not differing from the other methods of construction when maintenance is conducted in due manner. Commenced in Poland in the seventies of the last century this construction technology was stopped, however at the early nineties got new impulse and it is still developing.

The wood-framed with sheathing in the form of large panel or modular three dimensional 3D are the most often used technology. This kind of buildings are actually constructed up to four storey as a multifamily or varying universal buildings like school, kid-garden or offices.

Low dead load from 0.30 to $1.00 \mathrm{kN} / \mathrm{m}^{2}$ and its favorable proportion to the live load increase energy saving factor in realization and within the exploitation time (Miedzialowski, Malesza 2006). Low own weight of structure enables complete prefabrication of wall, floor and roof panels, improving quality of construction and shortening time of construction. Process of prefabrication, wide assortment and variety of factory production does not require time consuming processes and complicated moulds or shuttering indispensable in precast RC structural elements. 


\section{Shrinkage and swelling}

In process of swell and shrinkage the moisture content is changed in wood fibers (wall of cells), causing variation in volume while free water in empty spaces of cells does not have significant influence on this change Hence deformations with shrinkage and swell appear in the hygroscopic range below the state of saturation point, at about moisture content $W=30 \%$. Wood deformations in result of swelling and shrinkage do not appear in the capillary stage above the fiber saturation point, when the moisture content is higher than $W=$ $30 \%$. In three main anatomic directions of wood significantly large differences in shrinkage and swell are appearing. The highest strain of swell is noticed in direction tangential to the annual rings, while in the radius direction of rings is $50 \%$ lower, and in the longitudinal direction the swell strain is negligibly small, as well as in case of shrinkage strain (Mohammad 2006).

Linear dependence wood moisture-shrinkage/ swelling strain in the hygroscopic range is limited to values round from $W=5 \%$ to $W=20 \%$. It can be assumed with adequate precision for practical purpose, that linear dependence between alteration of form and moisture content changes is spread from $W=0 \%$ to $W=30 \%$.

Swelling and contrary acting shrinkage are approximately equal in value and they are in large degree reversible. Values of shrinkage or swelling vary for different kind of wood. Increase in density of wood cause rising deformation of shrinkage or swelling, because fibers in higher degree share the volume. Higher density wood induce larger deformation under change of moisture comparing to soft wood. These parameters are recognized for practical evaluation of swelling and shrinkage according to DIN Standard 52184.

\section{Deformations and defects in wood}

Process of drying after assembling of solid wood elements lasts dependently from environment conditions causing shrinkage of wood. Also deformations under compression perpendicular to grain in result of local bearing of compressed timber posts supported on horizontally assembled joists or headers are rising in time of loading lasting, what is shown in Figure 1 (CSA 1992).

Wood varies in color, grain, knot pattern, tendency to split or stain, and other features that can affect the look of a log and quality of wood (Marcondes,
Singh 1992). The following is a list of the most common defects in timber. Each defect can seriously affect the acceptability, grade and use of timber. There are structural defects of timber shown in Figure 2: knots, shakes, waney edge, encased barks, growth rate, resin pocket. Varying factors are influencing defects in wood: considering the growing of wood, there are different knots, eccentrically located core, twin core, helix around the stem cell orientation (spiral gram), grain twisting, varying kind of splitting and freezing splitting.

There are two kinds of knots: live knots and dead knots. With regards the strength and appearance of timber, and apart from the conditions of the knot, it should be considered: the size, the location and the number of knots. The larger is knot, the grater is the reduction in strength of timber. Knots nearer the edge of joist or board reduce the strength more then if they are nearer the centre. Large number of large knots decrease the strength more than greater number of small knots.

Knots appearing on the widest faces of timber are called face knots, edge knots are located on the narrow sides or edges of element, arris knots are located between a face and an edge, knots being cut through their
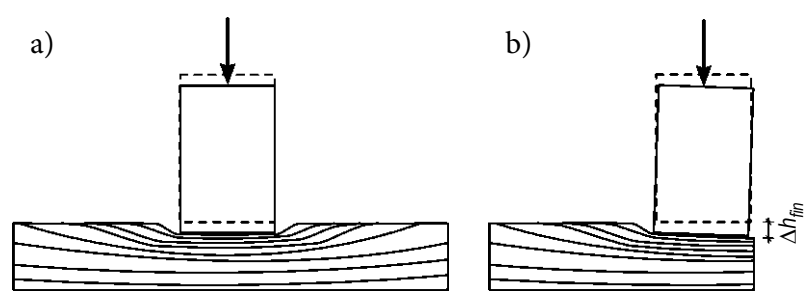

Fig. 1. Deformation under loading perpendicular to grain: a) deformation under internal stud , b) deformation under side stud (Carpenter et al. 1989)

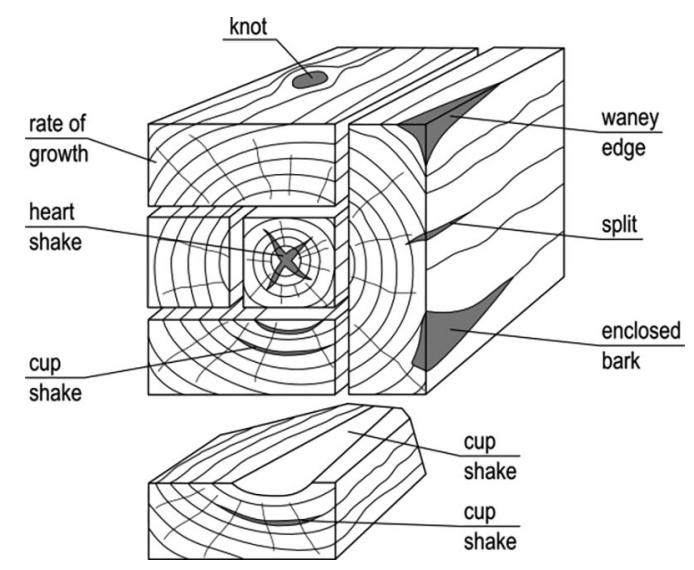

Fig. 2. Natural defects in wood (CSA 1992) 
length either fully or partially are called splay knots and knots in group are called cluster knots. Knots creating $\mathrm{V}$ litter close to core are called wing knot.

Cracking along the grain does not eliminate timber element as useful for structure. All kind of cracking transverse to the fiber and cracking visible in all cross section create hazard for structural element. Spike knots through the width or height of structural element create wicker place and may lead to failure. Element with such defect shown in Figure 3 cannot be built-in structure.

Paper examines influence of shrinkage on static behavior of timber structure, however some results of wood defects in the form of knots are considered with their influence on selected roof structural elements in the wood-framed residential building.

\section{Wood-framed building and technology of construction}

Several systems of construction in the frame of the wood-framed technology is recognized. There are three systems of technology:

- line system of construction, where elements are constructed on the site; studs, wall plates, joists, rafters, sheathing,

- large two dimensional (2D) panel construction system, where wall, floor and roof diaphragms constructed in the factory, next are assembled at the site of construction,

- three-dimensional (3D) system of spatial elements - modular construction.

Increasing demand on this kind of construction due to practical energy saving, possibility of free form creation and tend towards shortening of construction time lead the way to industrially provided construction through the factory made wall, floor and roof panels almost completely finished with built-in installations, then transported to the site and assembled.

Buildings realized in the line system of construction and in the large panel system of construction is show in Figure 4.

Industrial production of wall, floor and roof structural panels (Karacabeyli, Desjardins 2011; Schickhofer, Thiel 2011; Gagnon 2011; AI 2001), requires observing of technology regime, what in methods of construction directly on the site are descending unfavorably influencing durability and reliability of structure and all building required in PN-EN 1990 in respect of 50 years of exploitation preserving class of consequence failure $\mathrm{CC} 2$, the class of reliability RC2 and adequate inspections of realization and the index of reliability $\beta=3.8$ for ultimate limit state. These requirements impose rigorous demands in respect of materials quality, solution in design and compliance
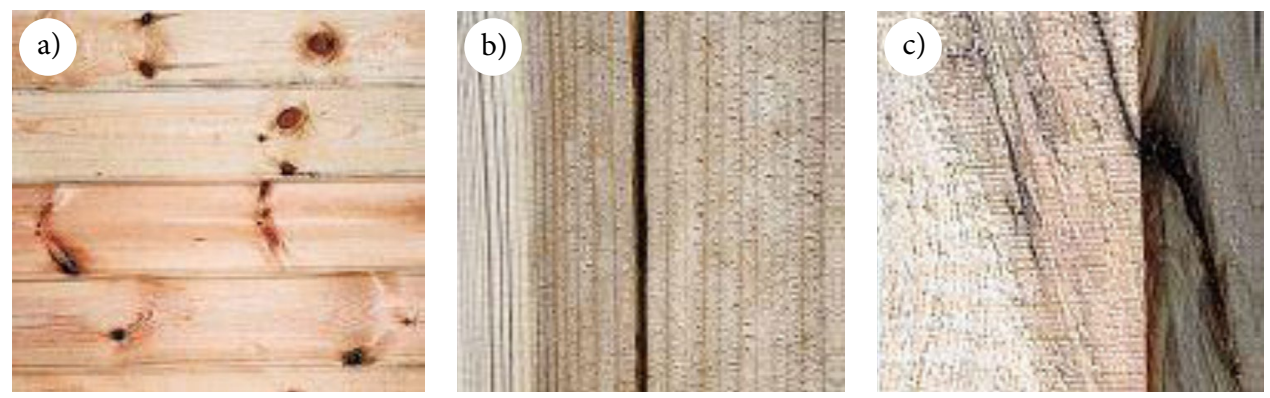

Fig. 3. Defects in wood a) wing knot, b) cracking along the grain, c) spike knot
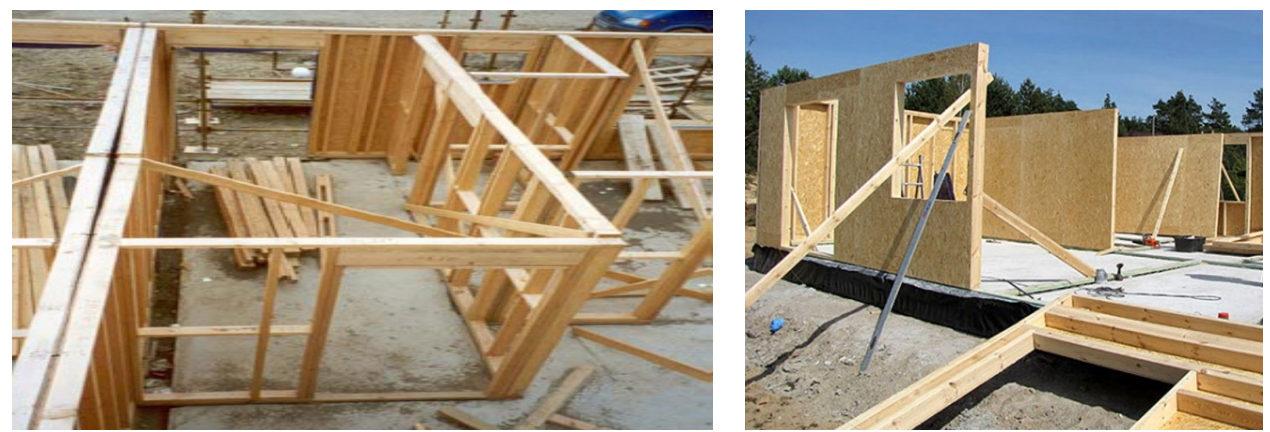

Fig. 4. Building constructed in the line system and in the large panel technology 
of construction with design. These demands can be preserved in factory realized prefabricated units within technological processes under control. However construction processes in part must be realized on site. There are interconnection of structural elements like wall-to-wall, wall-to-floor panel, wall-to-roof and wall-to-foundation (Mohammad 2006, NAHB 2002).

Correctly designed and assembled on site structure performs conditions of durability and reliability of all building, considering effects of drying wood within exploitation and process of shrinkage and arising gaps at joints and additional deformations. Faults and defects are partly eliminated in so called modular buildings where $3 \mathrm{D}$ spatial modulus are constructed in the factory within automatic process and then transported to site and assembled (CSA 1992; PATH 2003; Schmidt et al. 2000). Modules are assembled of formerly constructed foundations or basement, they are interconnected horizontally and vertically creating multifamily buildings, hotels, school, offices or commercial buildings. Assembled wall-to-wall module sometime higher than four story, create varying configuration building according to architecture form and design.

\section{Phases of industrial production}

Main stages of realization building in the wood-framed technology are show in Figure 5.

Individual elements like wall, floor, roof diaphragms are constructed in factory, on specialized production lines and then completed and assembled to $3 \mathrm{D}$ special module in case of modular construction according to diagram in Figure 6 (Schmidt et al. 2000; Smith et al. 2006).

In Figure 7 is presented partial completion of module in factory on the production line.

Production can be realized in stationary or directline production system, usually floor and roof diaphragms are constructed in stationary system, while walls are usually constructed on line. After completion units are transported to the site, sometime more than $500 \mathrm{~km}$, using different means of transport as it is shown in Figure 8.

Phase of transport is very often comparable to the repeatedly acting dynamic loading despite they

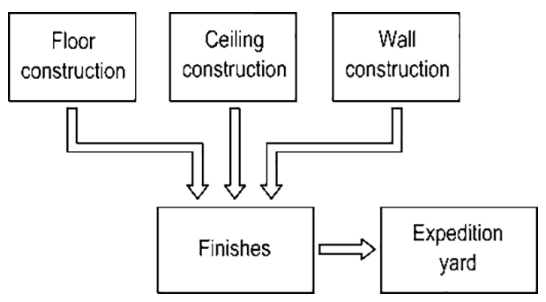

Fig. 6. Diagram of module assembling
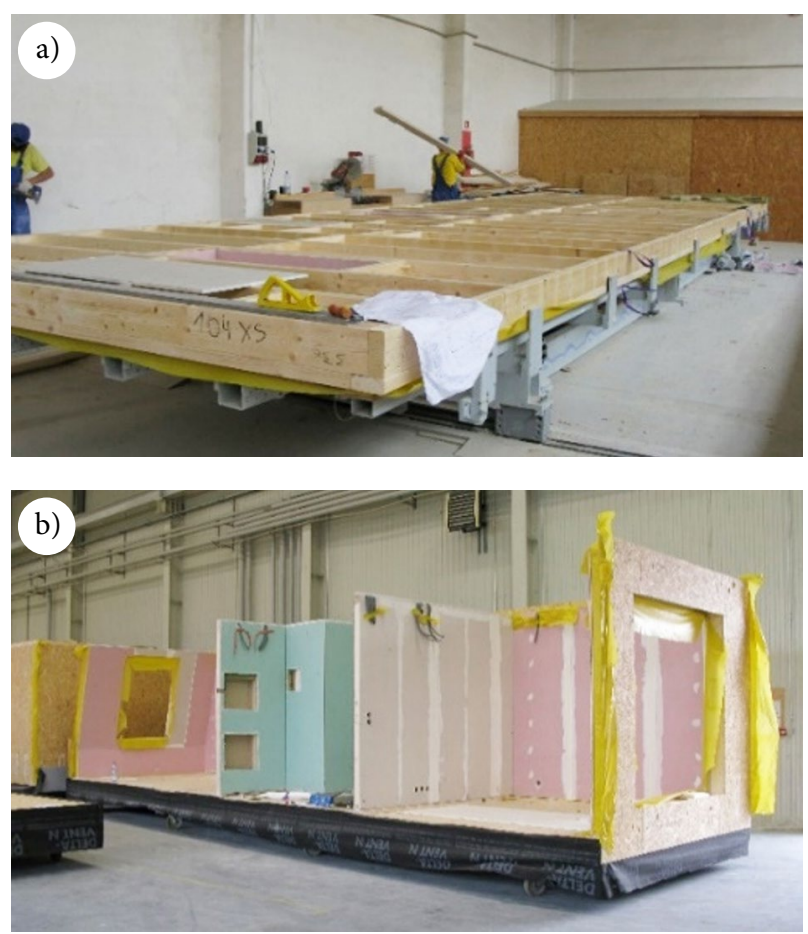

Fig. 7. Stages of module completion, a) element production, b) construction of module

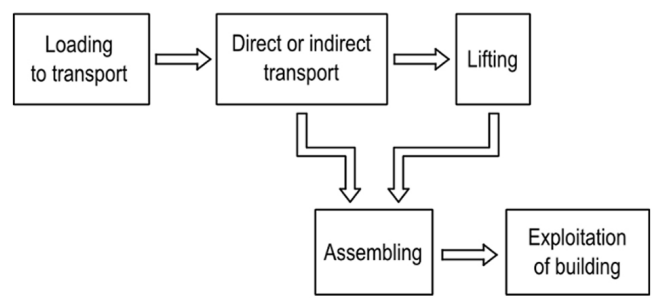

Fig. 8. Phases of transport and construction

are not of very high level. Within transport different accident loading may happen as a result of traffic collision or module slip-off (Asiz et al. 2005; Marcondes, Singh 1992). Transport route and road technical infrastructure are limiting the module dimensions. Usu-

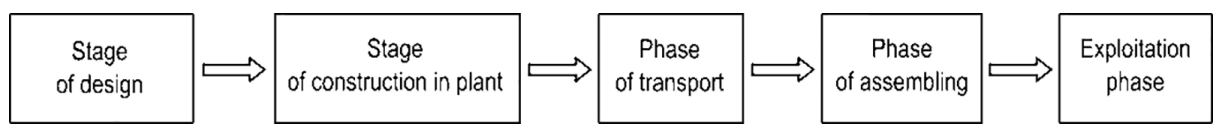

Fig. 5. Phases of realization of the large panel wood framed building 
ally the width does not exceed $4850 \mathrm{~mm}$, the height is limited to $4100 \mathrm{~mm}$ and the length is varying from $18300 \mathrm{~mm}$ to $19800 \mathrm{~mm}$. The own weight of single large panel element is varying from 1.50 to 3.00 tons and is dependent on dimensions and configuration of openings, while the weight of single module is varying from 15.00 to 16.00 tons $(160 \mathrm{kN})$. Stage of lifting and loading to transportation and preparing for this stage is presented in Figure 9.

Elements transported to the site are then assembled by crane directly from conveying vehicle. Elements are connected with screws or bolts on the
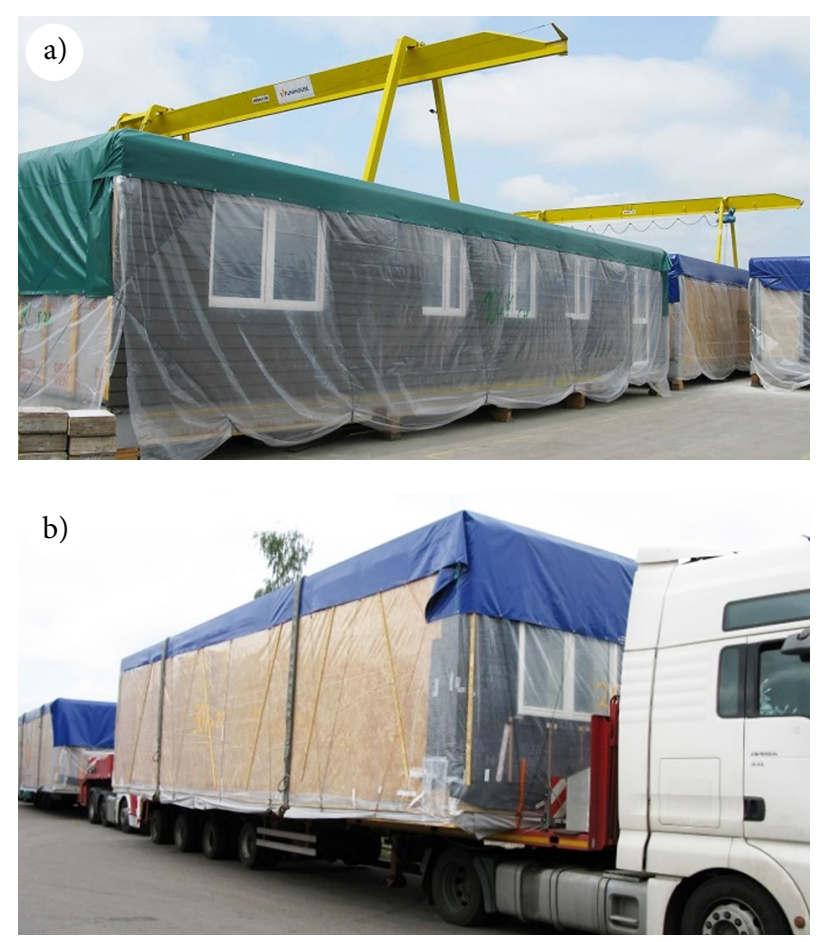

Fig. 9. Loading and transportation to the site height of floor panel, the twin walls are connected with screws. After assembling the gangs of finishing work subcontractors are completing building. Modules and their equipment in respect of installations are usually completed in $80-90 \%$ of whole range of work. Assembling of large panel building and module building is shown in figure 10.

\section{Static behavior of structure}

Safety of structure and adequate conditions of exploitation are the basic requirements for design of building. These requirements are resulted from static analysis and structural elements dimensioning and their connections (Lewicki 1964; Malesza, Miedziałowski 2011). All building should be designed with adequate spatial stiffness and geometrically invariant. Strains and displacements within the exploitation and in the assembling should fulfill adequate requirements and cracks especially in joints and connections are to limited. The first stage in process of design is evaluation of static scheme and elaboration of diagram reflecting structure of building, and then selection of dimensions, their formation and their interconnections. Structure elements than are subjected to static loadings and they have to fulfill required conditions of Ultimate Limit States according to formula (1):

$$
\mathbf{K d} \leq \mathbf{P}_{\mathbf{s}}
$$

where: $\mathbf{P}_{\mathbf{s}}$ is the matrix of internal forces under the most unfavorable combination of design loadings, $\mathbf{K}$ the stiffness matrix, $\mathbf{d}$ - displacements vector.

Expected errors in constructions and linear discrepancy or rotation and slip in joint should be tak-
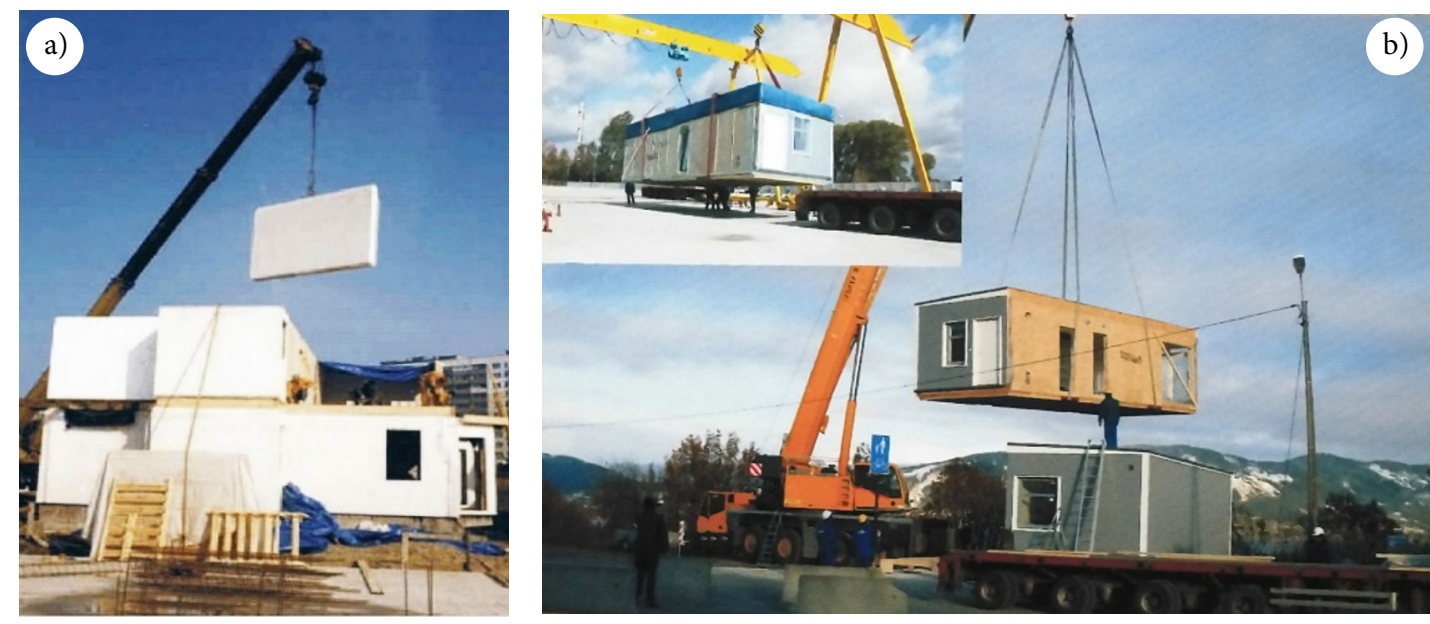

Fig. 10. Assembling of large panel building and module constructed building (Miedziałowski, Malesza 2006; Mohammad 2006) 
en into account in the process of design. Reactions arising in result of these errors like eccentrically assembled floor joists, eccentrically assembled panels of higher story, discontinuity in connections of walls are sometime neglected in static analysis, however their influence on behavior of structure may be significant. Design and static analysis evaluates internal forces for all combination of loading in EN 1990 for ULS and SLS and then dimensioning, but some structural requirements are resulted from non-structural conditions characteristic for the wood-framed technology of construction. Acoustic, moisture and thermal and fire protection requirements have significant influence on formation of structure. Usually in the static analysis and modeling of building structure the structural load bearing and shear walls are considered. In the woodframed structure bearing and non-bearing walls are statically cooperate for lateral loading, and they decide and determine the 3D - spatial stiffness of all building. In the wood-framed with sheathing buildings all walls are taking part in transmission of lateral load and distribution of horizontal load to adequate geometry and configuration of walls is given in figure 11. Designer should be aware to sometime insignificant failure of disconnections in joint may lead to unfavorable exploitation effects for whole building (Peleg 1984).

The stage of transport and lifting is usually omitted in static analysis. But the strains occurred during transportation process lead to exceeding stressing in selected elements comparing to the exploitation stage. Design of module shall include dynamic aspects of analysis. The equilibrium of Ultimate Limit State at the stage of transport and lifting ought to be described applying formula (2):

$$
\mathrm{Ma}+\mathrm{Cv}+\mathbf{K d}=\mathbf{P}_{\mathfrak{t}}
$$

where: $\mathbf{M}$ represents the mass matrix, $\mathbf{C}$ is the damping matrix, $\mathbf{K}$ - the stiffness matrix and $\mathbf{a}$ - the acceleration vector, $\mathbf{v}$ - the speed of transporting vehicle accompanied by wind velocity, $\mathbf{d}$ - displacements vector and $\mathbf{P}_{\mathbf{t}}$ - the internal forces. In case of lifting and assembling the formula (2) can be reduced to the form (3):

$$
\mathbf{M a}+\mathbf{K d}=\mathbf{P}_{\mathbf{t}}
$$

where inertia forces and external loadings are taken into account.

Significant factor influencing use of lumber and its future behavior in building depends on moisture factor and its changing within exploitation period. Varia-

a)

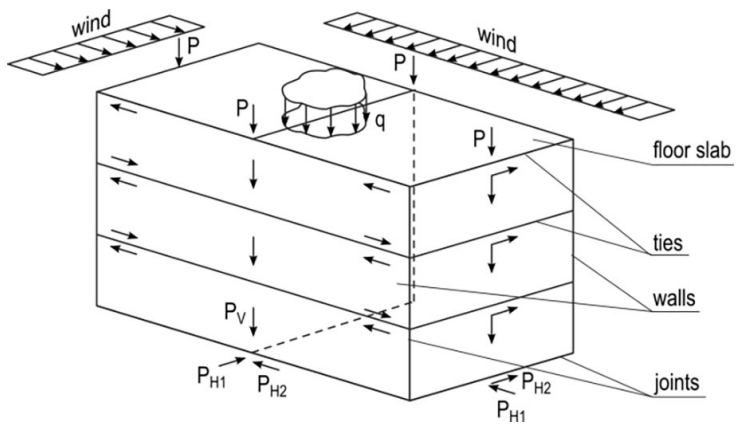

b)

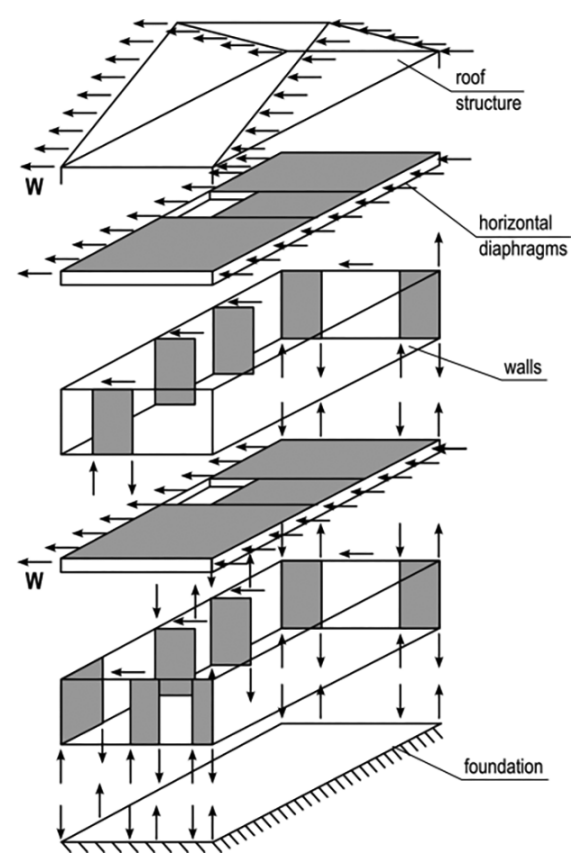

Fig. 11. Distribution of horizontal loading to the wall system (Malesza, Miedzialowski, 2006)

tion in moisture content cause shrinkage or swelling of timber elements. Radial and tangential to the annual rings of wood shrinkage is significantly higher than longitudinally. Radial shrinkage is twice lower than tangential for all kind of soft wood (Burch, Thomas 1991). Considering the effects of swelling and drying in result of moisture changing, dynamic analysis are required on all stages of design.

Selection of lumber and its moisture content factor decide on class of service and the ULS, SLS and on long-term factors influencing durability of timber structure. Measurement of moisture content in wood according to PN-EN 336:2004 create important information for process of lumber selection and factory made elements. This factor should be monitored in the large panels or module within the realization period and within the time of accommodation building for exploitation, as to obtain moisture equilibrium in elements. Referred moisture content is taken $20 \%$ (in 
EN 336:2004). It is assumed practically, that the height and the width of the cross-section decrease $0,25 \% /$ $1 \%$ of diminishing moisture factor below $20 \%$. Lost in moisture content on $10 \%$ corresponding to difference between the built-in element and moisture of element working in steady thermal-moisture conditions, may lead to significant difference along the height of building causing its deformations.

Design models can be evaluated with adequate engineering precision or taking into account all elements composing structure (Creighton 1997; Mi 2005; Schmidt et al. 2000; Smith et al. 2006). In the first approach the beam elements in numerical analysis is considered, while in the second stage $2 \mathrm{D}$ or $3 \mathrm{D}$ analysis is conducted.

Plane wall diaphragm is built applying beam elements nodal joined at edges and element of diagonal spring. Nonlinear stiffness of spring represents global shear stiffness of wall. Beam elements create additional nodes along the wall perimeter, where they are connected with the rest of structure. 3D model is built on the base of assumption of displacements and connections of plane elements.

In case of typical 3D structure the discrete method of FEM are used what is presented in Figure 12.

In 3D model elements of studs and plates (joists) are described using beam or shell elements, while sheathing is described applying the shell elements.

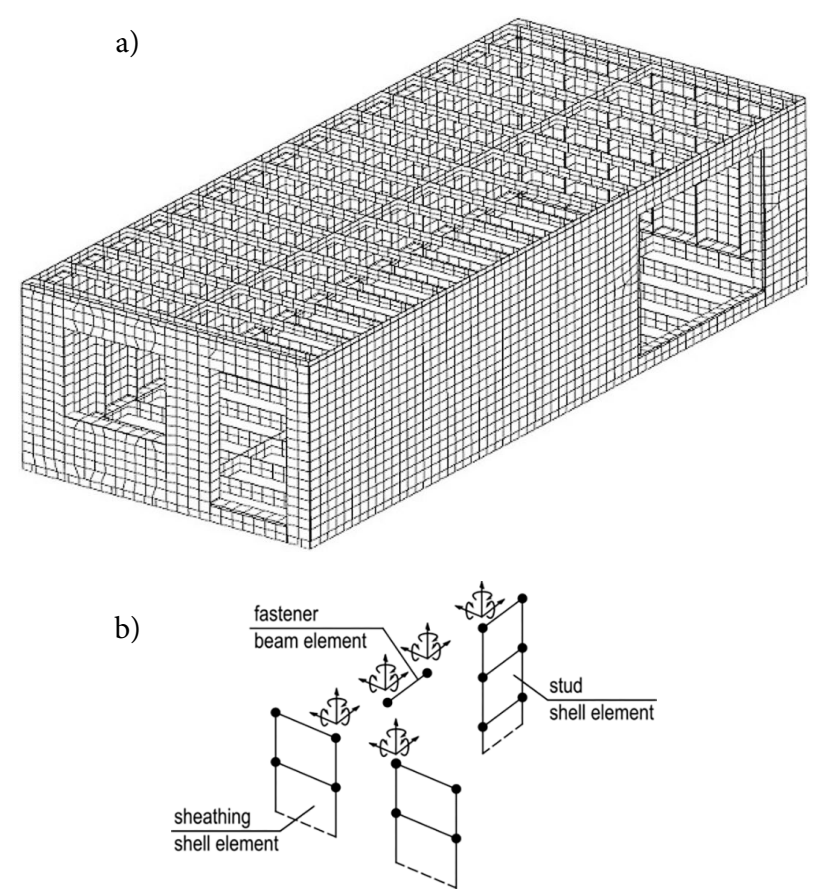

Fig. 12. Model of 3D structure based on FEM
Fasteners linking shell elements are described applying beam elements, where their parameters includes response of wood on linking fastener according to procedure presented in (Miedzialowski, Malesza 2006; Smith et al. 2006).

Shrinkage in result of drying influencing the cross-section dimension and causing changes in these dimensions as it is shown in Figure 14. Varying dimensions in result of moisture content changing has influencing the structure deformations and displacements.

The $2^{\text {nd }}$ class of service requires use lumber of $15 \%$ the moisture content. KVH wood with the cross sectional dimensions up to $300 \mathrm{~mm}$, according to CE represents the measured moisture content in the plant realized panels or modules has moisture content adequately $15(+2) \%$. Phase of traffic transport on the distance of $600-700 \mathrm{~km}$ and additional sea shipping and stockyard at the sea port awaiting for assembling causes rising in moisture content despite tight protection of all 3D element. This increase in moisture on $5 \%$ cause the moisture content of wood rising in time of erection to $20 \%-23 \%$. After assembling and commencement of finishes in building, all interiors undergoes heating causing changing in the thermal-moisture conditions inside and it brings lumber to lost of moisture in solid wood. Shrinkage (Breyer et al. 2014; Neuhaus 2004) is varying from $8-12 \%$ and depends on radial or tangential carved direction to the annual ring (Kozakiewicz, Krzosek 2013). Local bearing perpendicular to grain in wood cause additional deformations significant to future total deformations in building.

\section{Shrinkage deformations and stresses (static and extra-static) in buildings}

Strain and deformations of structural elements within the construction and exploitation shall be adequately small especially in the joints. Deformations in the form of deflections of floor joists, beams, girders or roof rafters are to be checked in static analysis and they are to be kept in allowable values. Allowable values of deformations depends on static scheme, element dimension, their form and connections and they are part of standard requirements. Also deviations and assembling errors, simplifications in analysis, neglecting some acting and reactions like strain or slip in joint are to be considered in the process of design. Dimensions and shape of element in the wood framed with sheathing buildings depends on nonstructural requirements. 
Acoustic, thermal and fire protection requirements have very often significant influence in formation of the structure.

Moisture is considered as a parameter deciding on use of timber as the structural element. Moisture content decide on future behavior of wood in structure. Class of service and in consequence Ultimate Limit State and Serviceability Limit State depend on moisture content in wood and moisture is influencing long term factors deciding on durability of timber structure. Moisture measurement according to PN-EN 336:2004 Standard is significantly influencing selection of lumber and process of fabrication of structural elements in the plant. Monitoring of moisture shall be conducted within all time of realization, adaptation of building to its exploitation has value of to obtain moisture equilibrium in elements. As a reference moisture is taken value of $20 \%$ (in PN-EN 336:2004). It is practically assumed that the height and the width of the cross-section is diminished on $0.25 \% / 1 \%$ of decrease of moisture below $20 \%$. Taking into account difference in moisture of built-in element working in constant thermal-moisture comfort, adequate moisture lost to value of $10 \%$ or even below may lead to significant differences in the dimensions of structural elements and to building deformations in result.

Variation in moisture content cause shrinkage or swelling of structural elements. Shrinkage is the highest directed to the annual rings, and it is 50\% lower in radial direction, while it is often negligible along the grain (Burch, Thomas 1991). This effect cause variation in dimensions of low and high timber buildings. In multistory building it evokes significant changes in the cross-section dimensions of structural elements leading in result to final deformations and additional internal forces. The sum of horizontal top and bottom plates of walls and floor joists cross-section dimensions in each module segments may provide in result rising of large vertical deformation not always symmetric. Typical section through the wall of woodframed building is shown in Figure 13.

\section{Analysis of shrinkage influence in structure}

Shrinkage changes of the cross-section dimensions in the wood-framed with sheathing buildings can be evaluated on the base of constant strain shrinkage wood deformations. This strain deformation according to Miedzialowski, Malesza, 2006) can be taken in value

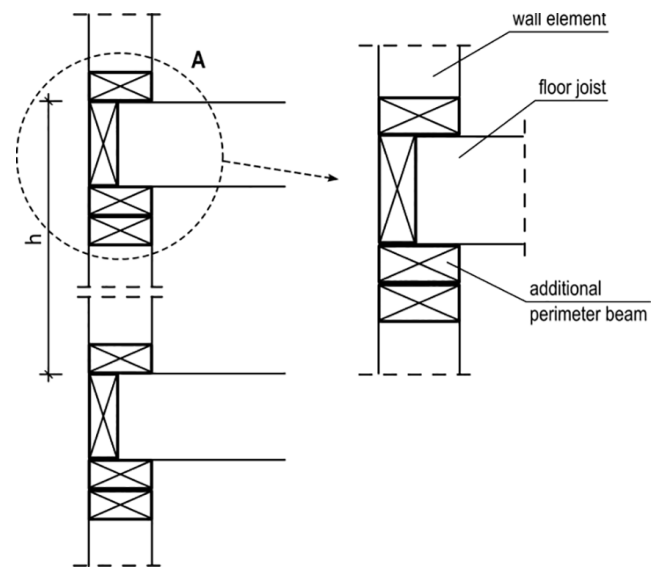

Fig. 13. Cross-section of wall and horizontal elements having influence on additional deformations of structure

of $6 \%$ for the width and the height of the cross-section for wood moisture content from ) \% to free saturation point $W=30 \%$. Influence of moisture content changing and shrinkage of wood elements deformation in the wood framed with sheathing building has been analyzed on the example of soft (fir) wood used in structure. Value of shrinkage strain for $1 \%$ of wood moisture content changing is obtained from formula (4):

$$
\varepsilon_{s}=0.25 \% / 1 \% \text { of } W .
$$

For the height $h$ of timber cross-section element, total shrinkage can be evaluated from formula (5):

$$
\Delta h=\varepsilon_{s} \times h \times \Delta W,
$$

where: $\varepsilon_{s}$ - shrinkage strain, $h$ - the height of the cross-section of horizontal timber structure element, $\Delta W$ - change in wood moisture content.

Wood moisture content of structural elements used in construction of the wood framed buildings has the value of $\mathrm{W}=18 \%$. Deformations on the height of cross-sectional dimension of the floor joists $60 \times 220$ $\mathrm{mm}$ over the ground floor and over the first floor reach the value:

$$
\Delta h_{1}=2 \cdot \frac{0.25}{100} \cdot 220 \cdot(18-6)=13.20 \mathrm{~mm} .
$$

Headers and the wall bottom ground plates of cross-section 50x150 and 60x150 mm

$$
\Delta h_{2}=\frac{0.25}{100} \cdot(8 \cdot 50+60) \cdot(18-6)=13.80 \mathrm{~mm} .
$$

Longitudinal shrinkage deformation of studs and the other vertical elements in wall panels is considered as equal zero, insignificant for total shrinkage deformation. 
Hence, total deformation in result of drying wood within the time of exploitation on the height of two story residential building constructed in the woodframed technology can be evaluated as:

$$
\Delta h=13.20+13.80=27.00 \mathrm{~mm} .
$$

Evaluating shrinkage deformation the real initial and exploitation values of wood moisture content should be measured and accepted in the process of design. Initial moisture content for timber used in the wood-framed with sheathing construction according to standards requirements shall not exceed $18 \%$.

As it comes from investigation reports, exploitation moisture content in the residential buildings is varying from $6 \%$ to $12 \%$.

Deformation in result of bearing and perpendicular to grain loading in timber element can be calculated from formula (6):

$$
\Delta h_{\text {inst }}=\frac{\sigma_{d}}{E_{90, \text { mean }}} \cdot h_{i},
$$

where: $\sigma_{d}$-stressing perpendicular to grain in horizontal element, $E_{90, \text { mean }}$ - Modulus of Elasticity in the direction perpendicular to grain, $h_{i}$ - the height of the cross-section the loaded perpendicular to grain element.

Considering the long term effects and creep, deformation is described in the form (7):

$$
\Delta h_{\text {fin }}=\Delta h_{\text {inst }}+\Delta h_{\text {creep }},
$$

where: $\Delta h_{\text {inst }}$ - instant deformation under loading perpendicular to grain, $\Delta h_{\text {creep }}$ - creep, long term influence on loading deformation.

With accordance to PN-EN-1995 1-1, creep deformation can be evaluated from formula (8):

$$
\Delta h_{\text {creep }}=\Delta h_{\text {inst }} \cdot\left(1+\psi_{21} \cdot k_{\text {def }} \cdot\right),
$$

where: $\psi_{21}$ - coefficient influencing time of loading on deformation, $k_{d e f}$ - factor influencing creep increase on deformation for adequate class of service in structure.

Deformation in multistory building may lead to significant deformations of whole building structure:

$$
\Delta h_{i}=\Delta h_{w}+\Delta h_{f i n},
$$

where: $\Delta h_{w}$ - additional deformation in result of moisture content change and shrinkage, $\Delta h_{f i n}$ - additional deformation in result of compression perpendicular to grain in multistory building.

Under compressed stressing perpendicular to grain under post in the wood-framed wall loaded with average stressing perpendicular to grain of the bottom plate is $\sigma_{c, 90, d}=2.12 \mathrm{~N} / \mathrm{mm}^{2}$, while under timber column loaded with the bearing purlins and steel or glulam girders $\sigma_{c, 90, \mathrm{~d}}=3.25 \mathrm{~N} / \mathrm{mm}^{2}$ (taken from design), deformations were equal:

$$
\Delta h_{\text {inst }}=\frac{2.12}{370} \cdot(50+50+6)=0.92 \mathrm{~mm}
$$

under typical wall stud and

$$
\Delta h_{\text {inst }}=\frac{3.25}{370} \cdot(50+50+6)=1.41 \mathrm{~mm} .
$$

As an example, for two story residential building constructed in the wood-framed technology, the total vertical deformation of the highest story may reach the value of:

$$
\Delta h=27.00+1.41=28.41 \mathrm{~mm} .
$$

Including effect of creep in deformation under loading perpendicular to grain, total displacement in two story building reach the value of:

$$
27.00+1.41(1+0.8)=29.54 \mathrm{~mm} .
$$

Displacements under deformation in result of stressing perpendicular to grain is insignificant and for low (usually two story residential buildings), while deformations under changed wood water content should be foreseen at the stage of design.

In the four storey building constructed in the wood-framed modular technology, where the sum of horizontal transversal joists and plates dimensions of the cross-section is assumed to be $630 \mathrm{~m}$, and the moisture content is decreasing on $\Delta w=12 \%$, hence the vertical deformations due to shrinkage reach the value:

$$
\Delta h_{w}=12 \cdot \frac{0.25}{100} \cdot 630=18.90 \mathrm{~mm} .
$$

Deformations due to bearing perpendicular to grain under column and stud for average vertical loadings in these elements assumed on the base of constructed real building is $31.0 \mathrm{kN}$, than deformation obtain value:

$$
\Delta h_{i}=\frac{31 \cdot 10^{3}}{2 \cdot 50 \cdot 120 \cdot 370} \cdot 630=4.40 \mathrm{~mm} .
$$

For four story building the sum of vertical deformations may reach the value of

$$
\Delta h=18.9 \times 4+4.40=80.00 \mathrm{~mm} .
$$

Including long term effect of deformations due to bearing under load perpendicular to grain the total deformation is assumed to be:

$$
\Delta h=18.9 \times 4+4.4 \times(1+0.8)=83.52 \mathrm{~mm} .
$$

This deformation requires special treatments in elimination and diminishing their influence on habitants within time of exploitation. 


\section{Selected defects in timber buildings}

\subsection{Wood-framed with sheathing building}

Failures of roof timber structure in the form of cracking were discovered in inventory of structure. Location of defects in roof timber panels and wall elements were in wood-framed building and in the log wall buildings. Selected examples of material defects and failures were localized and described.

Damaged joist allocated at the gable wall as the first beam of floor. The joist is insignificantly loaded and no additional deformations were noticed. This element was built with natural defect in. Location of knot and orientation of grain at the knot location initiated splitting and failure in result. The length of splitting $340 \mathrm{~mm}$ and width of cracking (splitting) $4 \mathrm{~mm}$ indicates that timber joist with such defect should not be built-in the structure.

Except natural or drying effects in wood unexpected construction errors brought structure to static hazard. Ridge beam working as the upper purlin supporting rafters was assembled incorrectly. Rafters were not directly supported on the ridge beam.
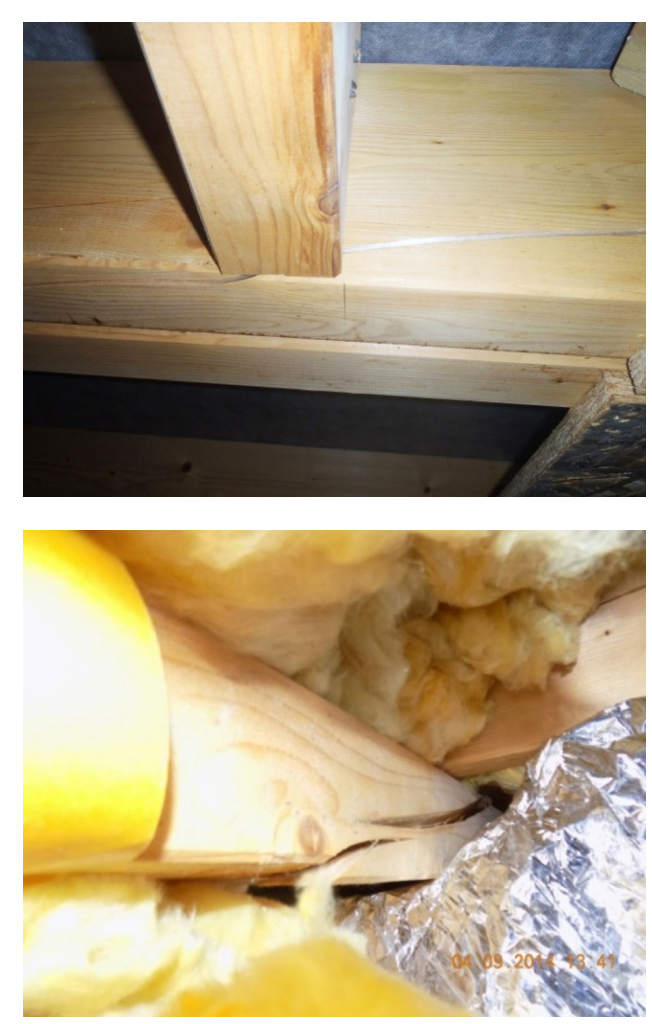

Fig. 14. Splitting of the bottom grains in the roof rafter at the bracing element, double rafter elements (two panels) cause distribution of loading to sound neighboring element and elimination of excessive deformations, failure damage of joist in the floor over the second floor.
Static scheme of roof rafters according to the former design for details of a) in Figure 15 and diagram of bending moment in the rafter with horizontal reaction to the external wall is shown in Figure 16.

Changed in construction support condition at the ridge beam of rafter create different diagram of bending moment and increased horizontal reactions to the exterior walls as it is shown in Figure 17.
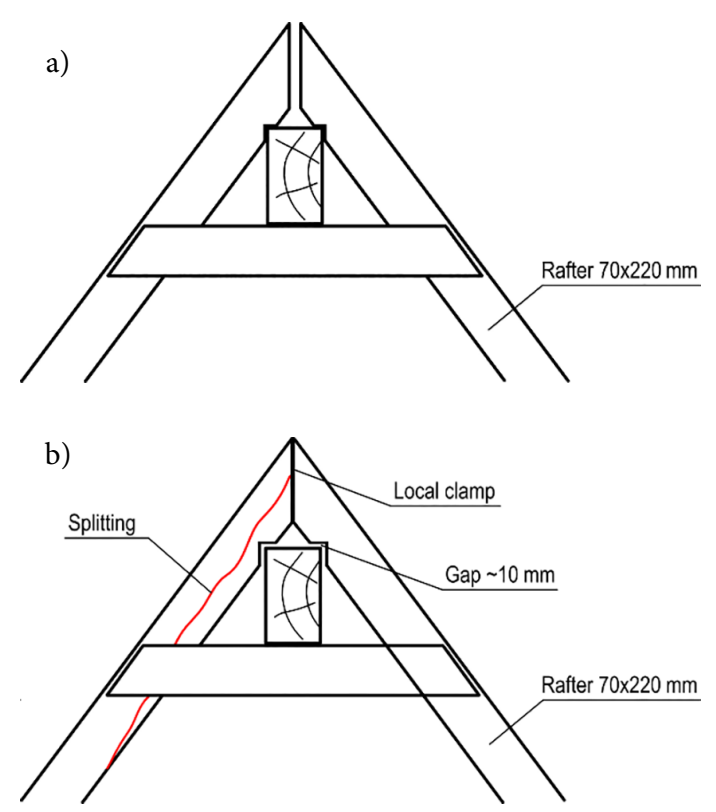

Fig. 15. Details of rafters supported at the ridge beam: a) according to the original design, b) constructed on the site

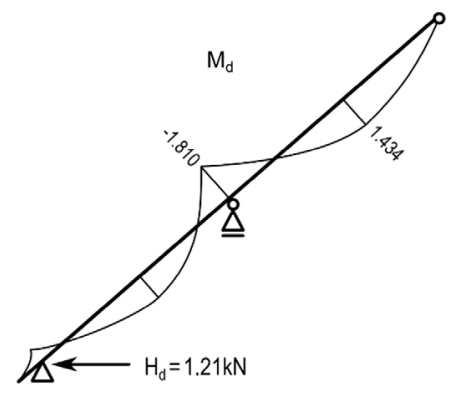

Fig. 16. Diagram of bending moment in the rafter and horizontal reaction to the header of external wall

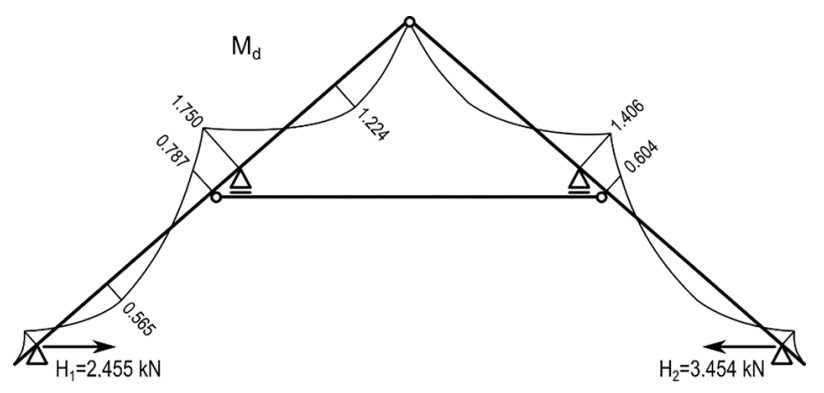

Fig. 17. Diagram of bending moment in the rafters in changed static scheme and horizontal reaction to the header of external wall 
Eliminated direct support for rafter causes change of roof structure static scheme, providing different distribution in internal forces in rafters and reaction to the wall. Arising horizontal reaction to the first floor walls connected with floor slab over the ground floor and with ground floor walls were not designed to transmit these forces. Internal forces in the roof timber frame structure with changed static scheme without support on ridge beam under combination STR for dead load and live load evaluated in structural design were analyzed. The roof rafter has been analyzed for two span continuous beam in the original design static calculation, under condition that rafter is supported on the ridge beam. Assembling and construction of roof structure cause modified static scheme in result of elimination ridge beam as the rafter support. Changed static scheme of roof structure and eliminated support on the pole purlin create significant horizontal force to the bottom plate. These horizontal forces higher in value than estimated in original design were acting to the wall headers causing horizontal displacements of wall and cracking finishes inside.

\subsection{Timber log wall buildings}

Round wall log dia. $170 \mathrm{~mm}$, floor joists height of 200 $\mathrm{mm}$ and roof rafters height of $180 \mathrm{~mm}$ were class of 24 soft pine and fir wood with approximate moisture content $20 \%$. These elements were built-in the structure of one story traditional timber building. Within one year of natural drying varying natural defects were detected. The moisture content in the early exploited building was checked and steady as $10 \%$, and in some internal walls even $8 \%$. Almost all elements in the walls, floor and roof undergo cracking in result of wood shrinkage and warping. Different finishes inside were to be replaced by new material. Figure 18 presents splitting of loaded vertical elements.

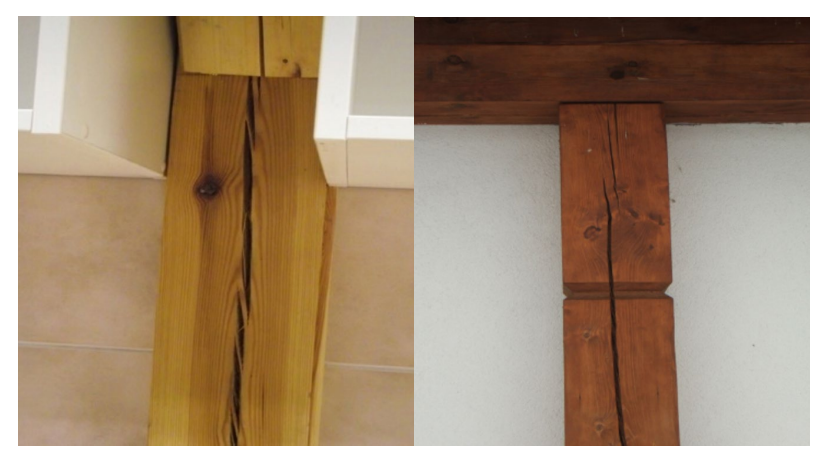

Fig. 18. Supporting post splitting in result of shrinkage
Wood used in timber structure shall fulfill requirements of the Standard PN-EN 14081 in respect of natural faults and moisture content in function of future class service and strength requirements adequate to class of solid wood in PN-EN 338:2011 Standard. Besides wood for structural purpose shall be marked as $\mathrm{CE}$ adequate building material.

\section{Repair and remedial works in examined buildings}

Changed static scheme of the roof structure has been recovered to the primary designed state through elimination of gaps between ridge beam and rafters, infilling free space between elements by steel plates and resin glue.

Splitting in vertical elements has been infilled with resin glue and tightened with strong-drive timber screw $0.22 \times 4$ " spaced on $100 \mathrm{~mm}$ along the column.

\section{Conclusions}

Timber buildings require special approach at the stage of their design and exploitation in respect of recognize wood defects and varying properties of wood. Paper presents selected natural defects of wood and influence of moisture content changes on shrinkage and swelling causing geometric deformation of structural elements. Changed moisture content, natural cracking and splitting within exploitation time, knots and relatively high stressing deformation depending on directed to the grain loading are influencing degree of deformation of timber structure. Direct natural wood defects like cracking and knots in wood create hazard for Ultimate Limit State and Serviceability Limit State and require repairs and strengthening of structural timber elements. Defects and damages of wood used for construction within exploitation in result of increasing or decreasing moisture content changes may lead to deformation and overloading. Stressing deformations cause nonstandard changes in geometry not only in respect of excessive serviceability limit state but also in function of building when comparing to masonry or concrete staircase or lift boxes, drying timber lead to differences in floor level comparing to designed. These differences are to be eliminated, when process of drying of wood in ended and splitted or cracked elements shall be repaired. Selected way of strengthening and repairs of defected elements applying epoxy bonded steel plates inserted in the formed gaps between wood grains in 
result of cracking under perpendicular to grain tension, allow to elongate technical life of structure.

Construction in factory, transport, lifting, and assembling of the large panels or modular buildings in the wood-framed technology is a complicated production, logistic and organization building process. This process requires detailed planning and monitoring at each phase of design and realization. Selection of lumber with adequate specified parameters, controlled process of design and monitored process of construction where elimination of errors and elimination of unexpected deformations will give final product of expected quality. Additional vertical deformations in the form of sum varying moisture content, deformation in result of load bearing perpendicular to grain and long term (creep) deformation in four story building may give $64.62 \mathrm{~mm}$ in the three-story building in the wood-framed technology. This final deformation shall be foreseen at the stage of early design as to partially or completely eliminate it in exploitation.

\section{References}

Asiz, A.; Iranpour, M.; Smith, I. 2005. Analysis of structural stresses during handling and transportation of factory-built housing construction, in Proceedings of 33rd Annual Conference of the Canadian Society for Civil Engineers, 2-4 June 2005, Toronto, Ontario, Canada, Vol. 2, CD-ROM, 8 pp.

Breyer, D. E.; Fridle, K. J.; Cobeen, K. E.; Pollock, D. G. 2014. Design of wood structures - ASD/LRFD. $7^{\text {th }}$ ed. New York: McGraw-Hill Professional Publications.

Burch, D. M.; Thomas, W. C. 1991. An analysis of moisture accumulation in a wood frame wall subjected to winter climate: Final Report. Gaithersburg: The U.S. National Institute of Standard and Technology.

Canadian Standard Association (CSA). 1992. Manufactured Housing/Mobile Homes, Standard CAN/CSA Z240, Ottawa, ON.

Carpenter, R. D., et al. 1989. Defects in hardwood timber. Forest service Agriculture Handbook No. 678. Washington, DC.

Creighton, J. 1997. Finite element analysis of manufactured homes under lateral loading: MS Thesis. Department of Civil Engineering, Colorado State University, Ft. Collins, USA.

Canadian Standard Association (CSA). 1992. Manufactured Housing/Mobile Homes, Standard CAN/CSA Z240, Ottawa, $\mathrm{ON}$.

Gagnon, S. 2011. CLT-Structural Design, in Symposium on Cross Laminated Timber, 8-9 February 2011, Vancouver, Canada.

Karacabeyli, E.; Desjardins, R. 2011. Cross laminated timber (CLT) in the context of wood building systems, in Symposium on Cross Laminated Timber, 8-9 February 2011, Vancouver, Canada.

Schickhofer, G. 2011. CLT European experiences, in Symposium on Cross Laminated Timber, 8-9 February 2011, Vancouver, Canada.
Kozakiewicz, P.; Krzosek, S. Inżynieria materiałów drzewnych. Warszawa: Wydawnictwa SGGW.

Lewicki, B. 1964. Budynki mieszkalne z prefabrykatów wielkowymiarowych. Warszawa: Arkady.

Malesza, J.; Miedziałowski, Cz.; Malesza, M. 2013. Modułowe budynki o konstrukcji szkieletu drewnianego, Materiały Budowlane 12.

Malesza, M.; Miedziałowski, Cz.; Malesza, J. 2011. Kształtowanie i projektowanie współczesnych konstrukcji drewnianych. Oficyna Wydawnicza Politechniki Białostockiej.

Malesza, M.; Miedziałowski, Cz. 2006. The wood-framed with sheathing buildings - alternative for housing construction, Journal of Civil Engineering and Management 12(2): 143-151.

Marcondes, J.; Singh, P. 1992. Use of road roughness to predict vertical acceleration in truck shipments, Advances in Electronic Packing, American Society of Mechanical Engineers, 999-1004.

Mi, H. 2005. Behavior of unblocked shear wall: Master of Science Thesis. Graduate Academic Unit of Forestry and Environmental Management, University of New Brunswick, Fredericton, NB.

Miedziałowski, Cz.; Malesza, M. 2006. Wood-framed buildings with sheathing: basis of structure mechanic, construction and design. Warsaw: Bialystok University of Technology (in Polish).

Mohammad, M. 2006. Connection systems for prefabricated wall panels: Final Report, No. FCC25. Natural Resources Canada, Ottawa, ON.

National Association of Home Builders Research Center (NAHB). 2002. Advanced Panelized Construction - Year One Progress Report, prepared for Partnership for Advancing Technology in Housing (PATH), Washington, USA.

Neuhaus, H. 2004. Budownictwo drewniane: Podręcznik inżyniera. Polskie Wydawnictwa Techniczne Rzeszów.

PATH Inventory. 2003. Modular multiple dwellings. Washington: Partnership for Advanced Technology In Housing.

Peleg, K. 1984. Impact and vibration testing of shipping containers, Journal of Sound and Vibration 93(3): 371-388. http://dx.doi.org/10.1016/0022-460X(84)90335-3

Schickhofer, G.; Thiel, A. 2011. CLT - Research and Testing at TU Graz, in Symposium on Cross Laminated Timber, 8-9 February 2011, Vancouver, Canada.

Schmidt, R. J.; Goodman, J. R.; Richins, W. D.; Pandey, A. K.; Larson, T. K. 2000. Improved design of manufactured homes for hazardous winds, in Proceedings of World Conference on Timber Engineering, 31 July - 3 August 2000, Whistler Resort, British Columbia, Canada.

Smith, I.; Asiz, A.; Dick, K.; Doudak, G.; Mohammad, M. 2006. Improving design concepts and methods through field-monitoring of timber buildings, in World Conference on Timber Engineering, 7-10 August 2006, Portland, Oregon, USA.

PN-EN 336:2004 Structural timber - Sizes, permitted deviations.

PN-EN 338:2011 Structural timber - Strength classes.

PN-EN 1995:2010 Design of timber structures. Part 1-1: General rules

PN-EN 14081:2011 Timber structures. General rules.

DIN 52184: 1979 Testing of Wood; Determination of swelling and shrinkage. 
Jaroslaw MALESZA. PhD in Bialystok University of Technology, Faculty of Civil and Environment Engineering. Author of papers in the branch of civil engineering structure, published in Poland and abroad. Co-author of monograph on Timber Structures. His main research works are actually focused on the following areas: structural analyses and investigations of the reinforced concrete, stiffness, stability and load bearing capacity of timber structure in civil engineering. Research and didactics at the University, close links with industry, through applied research, specialized testing including different materials used in various kind of timber structure. Long-term and creep tests of materials and joints, also investigations on durability of historical building. Designing works on various engineering structure for domestic and abroad investors. Structural design for civil engineering, industrial and sports projects. 